\title{
Yield Gap and Constraints in Jasmine Cultivation and Suggestions to Increase the Production in Tamil Nadu, India
}

\author{
A. Janaki Rani* and P. P. Murugan \\ Department of Human Development, Community Science College and Research Institute, \\ TamilNadu Agricultural University, Madurai, India \\ *Corresponding author
}

\section{A B S T R A C T}

Floriculture has emerged as an important sub-sector of agriculture as a source of income for small and marginal farmers. In India, Tamil Nadu state is the leading producer of jasmine with an annual production of 77,247 tonnes from the cultivated area of 9,360 ha. In Madurai District of TamilNadu, jasmine is being cultivated in an area of 1,250 hectares with an average productivity of 7.85 tonnes per hectare and is famous for its GI product

\section{Keywords}

Jasmine growers, constraints, preference/ problem ranking, strategies

Article Info

Accepted:

12 February 2020

Available Online:

10 March 2020 Madurai Malli. Even though the area is more the scientific way of cultivation is poor. The small and marginal farmers are facing many problems not only in cultivation but also in marketing their produce. Hence, they are unable to meet the demands of raw flowers required from industries and other countries. Keeping the above situations in mind, an attempt has been made to identify the yield gap and real problems faced by the farmers in production and marketing and also the prospects of this sector to stabilize the productivity. The study was carried out in Madurai District with jasmine growers through problem ranking method in participatory approaches. The results revealed that $1.3 \mathrm{t} / \mathrm{ac}$ of yield gap I was prevailing in jasmine and with respect to production constraints, unavailability and high cost of labour, pest and diseases, monsoon failure, lack of proper pruning were the major constraints. With regard to marketing constraints, commission agents, pre harvest agreements, heavy fluctuations in price, perishability nature, lack of technical guidance on export of flowers and awareness on GI were the constraints felt by the farmers. Awareness on recommended fertilizer and pruning management and proper chemicals for pest and disease control is felt essential among the farmers. Importance and benefits of Geographical Indication for Madurai malli should be disseminated among the farmers to get good market price in the national and International markets.

\section{Introduction}

Floriculture is a vital sub-sector of horticulture, having potential for providing enhanced returns to farmers and employment opportunities especially to small and marginal farmers and female labour (Kaviarasan et al.,
2015). Tamil Nadu is one of the top states in the production of jasmine in the country with an annual production of 77,247 tonnes from the cultivated area of 9,360 ha. The flowers produced in the state are being exported to the neighbouring countries viz., Sri Lanka, Singapore, Malaysia and Middle East 
countries. Among the major jasmine growing districts of Tamil Nadu, Madurai district, has an area of 1,250 hectares with an average productivity of 7.85 tonnes per hectare. Jasmine is grown nearly by 4,000 farmers in the district and it is famous for its GI product Madurai Malli.

Even though the area is more in Madurai district the scientific way of cultivation is poor. Further, majority of the Jasmine growers, belonging to small and marginal farmers' category are facing many problems not only in cultivation but also in marketing their produce. Hence, they are unable to meet the demands of raw flowers required from industries and other countries. Sivashankar and Shashidhar (2011) reported that marketing facility at local level was perceived as a major constraint next to non-availability of labour. Vairavan (2012) stated that Jasmine growers are toiling with numerous hurdles like price volatility, debt, non-availability of high yielding varieties, pests and diseases and absence of cold storage facilities. Heavy price fluctuations, lack of skills for garland makers and wide gap between demand and supply and commission agents are among the issues should be addressed by experts so that there will be more jasmine entrepreneurs in this region (The Hindu dated $13^{\text {th }}$ July 2012). Madurai Malli with its unique fragrance has huge demand in the market. Though demand is estimated at 10,543 tonnes, production is only 9,577 tonnes. The gap could not be bridged due to various challenges in the value chain. (The Times of India dated August 24th 2014)

Keeping the above situations in mind, an attempt has been made to identify the yield gap and real problems faced by the farmers in production and marketing and also the prospects of this sector in order to stabilize the productivity.

\section{Research Methodology}

The study was conducted in Madurai District of TamilNadu. In Madurai District Thiruparankundram block situated in south taluk was selected as the study area based on the maximum area (538 ha) under jasmine cultivation. Under Thiruparankundram block, three villages viz., Vedarpuliyankulam, Valayankulam and Alangulam were purposively selected based on the maximum area under jasmine cultivation. The data were collected from the farmers using PRA simple scoring and preference/problem ranking method.

\section{Findings and Discussion}

\section{Yield gap analysis}

Yield potential is defined as the yield of a crop cultivar when grown in environments to which it is adapted, with nutrients and water non-limiting and pests and diseases effectively controlled. Hence, for a given jasmine crop variety (Gundumalli) in a specific growth environment, yield potential is determined by the amount of incident solar radiation, temperature, and plant density. The difference between yield potential and the actual yield represents the exploitable yield gap. The yield gap of jasmine crop is calculated and presented in the table 20.

The results indicated that, the average yield of farmers were estimated and resulted in 2.3 t/ac as against the research station yield of 3.6 t/ac. Hence the difference is 1.3 t/ac. This yield gap is referred as Yield gap I. The yield difference in farmer's highest yield $(2.75 \mathrm{t} / \mathrm{ac})$ and average yield $(2.3 \mathrm{t} / \mathrm{ac})$ attributes were worked out. The difference is called Yield gap II $(0.45 \mathrm{t} / \mathrm{ac})$. Even though the area is more in Madurai district the scientific way of cultivation and the adoption of recommended technologies by the farmers is less and 
majority of the Jasmine growers, belonging to small and marginal farmers' category are facing many problems not only in cultivation but also in marketing their produce. This might be the possible reasons for majority of them have yield gap up to $1.3 \mathrm{t} / \mathrm{ac}$.

\section{Factors responsible for the yield gap}

There are different factors which induces the yield gap given in Table2. The Factors responsible for the yield gap were assessed through PRA-Simple Scoring method. This method is adopted by Andrew et al., (2010).In this method, the respondents were asked to place the stones based on the weightage of the problem faced by them. Each stone was given score of five and weightage of 5 per cent by which maximum of 20 stones can be used for highest preference $(100.00 \%)$.The range of the score will be 1 to 20 . Later the stones in each item were counted and weightage will be given and ranked according to the highest score and analyzed. Here we have assessed the factors responsible for the yield gap. It ranges from 35 to $85 \%$.

The results revealed in table 2 indicate that through PRA simple scoring method water scarcity for irrigation or drought situation was given first rank by most of the farmers. Because during the survey period they have undergone severe drought and even couldn't irrigate the field. This was felt by many of the farmers and placed highest stones.

Secondly, due to the continuous harvest of flowers in all the seasons they were not going for proper pruning management which automatically reduces the yield of jasmine. This was not realized by the farmers. Hence they felt this might be one of the reasons for yield gap.

The jasmine farmers felt that high temperature which reduces the quality of flower production (scorching and tip drying) might be the reasons for yield gap and ranked third. They expressed that use of complex fertilizers in improper ratios also one of the factors responsible for the yield gap.

Root rot and budworms are serious problems and face difficulties in their management. They expressed that they are applying pesticides weekly once during peak flowering seasons. Hence they felt that it as an important factor for yield gap.

The other factors responsible for the yield gap they expressed are lack of high yielding varieties, late picking of flowers which reduces the yield and quality of flower, seeking advice from private fertilizer and pesticide shops, keeping jasmine crop more than 10 years without crop rotation, lack of awareness on split doses and foliar spray and spending much amount for the management of iron deficiency.

\section{Production and marketing constraints}

The findings on production and marketing constraints obtained through preference/ problem ranking method are presented in the following tables 3 and 4 . The methodology followed for assessing the preference/problem ranking method is as follows. Totally, Six farmers group were identified to conduct Preference/problem ranking. Each group consists of 5 jasmine growers and totally 30 farmers were selected to do the preference ranking. Each farmer in a group has to assign marks from 1 to 5 based on the importance of the problems and severity of the problem. With reference to production and marketing constraints ten constraints were selected as items based on the discussions with farmers.

The researcher has proposed every item of problem for the preference of farmers. For every item of constraints proposed among the 
farmers in a group, the farmers started putting scores based on their preferences of importance of the problem. Then, the average scores arrived for each group is depicted in the table for further analysis. Likewise for every problem, group average scores were obtained and the score of each group is added and the mean value was arrived. For every problem item, the same procedure is followed. Finally, based on the mean value for each item of problem rank was assigned from 1-10. Preference/Problem ranking method helps to quickly get a good idea of what people think on the priority problem or preferences

\section{Production constraints}

The results indicated in the table 3 that, the unavailability and high cost of labour was given first preference by the six groups of farmers. They expressed that during peak seasons and flowering periods they face labour problem. Hence, they ranked it as first area of preference.

Secondly, they ranked pest and diseases problem as their major problem and ranked as second area of preference. The jasmine flower has a huge demand in the market. Hence the flowers affected by pest and diseases will be automatically graded low quality and rejected in international markets.

Due the drought situation prevailed in the study area they were suffering due to inadequate irrigation were expressed by the farmers and hence they ranked it as third area of constraints. The jasmine farmers felt that high temperature which reduces the quality of flower production scorching and tip drying might be the reasons. About 50.00 percent of the farmers were not doing proper pruning which affect the jasmine flower quality was expressed by the farmers. Pruning is an important for inducing side shoots and to increase flowering and hence it was ranked fourth by the farmers. This finding is in line with the findings of Ahiah (2013).

The farmers felt that adoption of recommended fertilizer doses was not followed by many of the farmers, further they apply the complex fertilizers rather than straight fertilizers, hence they ranked non adoption of fertilizer doses as the major problem to be addressed. High seedling cost(Rs.40.000), delay in input supply, lack of technical knowledge on split application and foliar spray and lack of subsides for drip irrigation were the other problems preferred by the farmers to be addressed.

\section{Marketing constraints}

The results presented in table 2 indicated that commission agents were felt as a major constraint in marketing. Because, the commission agents getting 12.5 percent commission for every Rs.100/-. Further, price fluctuations also one of the factors influenced by commission agents and hence they have given first preferences and given first rank. This finding is in line with the findings of Janakirani (1999)

Secondly they ranked pre harvest agreements as a preference area by majority of the farmers. The farmers are getting advance amount from the commission agents before they go for planting and in between operations and had an agreement and they are working like slaves in order to repay the amount got as advance.

During peak season the jasmine farmers are undergoing heavy price fluctuations in the price even an hour to hour. Hence they ranked price fluctuation as $3^{\text {rd }}$ problem to be addressed. Due to poor keeping quality of the flower it can't be kept for longer period of time was expressed and they need cold 
storage facilities in the marketing in order to stabilize the market price. Hence they ranked it as fifth preference area to be addressed.

Technical knowledge on export procedures of flowers to international markets for profit and the benefits due to the geographical indication was not known by majority of the farmers. Hence they preferred and ranked it as fifth area to be given attention. Lack of storage facilities, lack of grading and proper weighing machine for grading, intake of flowers for low prices by scent factories, high transport cost and low yield of flowers during off season were other problem areas preferred and ranked subsequently by the jasmine farmers. This findings are in line with the findings of Vasanthi (2015).

Jasmine with its unique fragrance has huge demand in the national and international market. Though demand is estimated at 10,543 tonnes, production is only 9,577 tonnes. The gap could be bridged if the above challenges in the value chain are addressed. Among the constraints studied the marketing constraints was felt much by the respondents than the productions constraints which got the Average Mean Score of 3.9.

With regard to marketing they need price stability during peak and lean seasons was expressed by 78.00 percent of the farmers. Nearly 75.00 percent of the farmers want awareness on recommended fertilizer and pruning management. Hence, ICT enabled knowledge empowerment may be given priority. In the study area the youth participation is higher and they expressed to export the jasmine. But they don't know the procedures. Hence, awareness may be given on export procedures.

Table.1 Yield Gap I and II in Jasmine cultivation

\begin{tabular}{|c|c|c|c|c|}
\hline $\begin{array}{c}\text { Potential } \\
\text { Yield }\end{array}$ & $\begin{array}{c}\text { Farmers } \\
\text { Average yield }\end{array}$ & $\begin{array}{c}\text { Farmers highest } \\
\text { yield }\end{array}$ & Yield gap I & Yield Gap II \\
\hline 3.6t/ac & $2.3 \mathrm{t} / \mathrm{ac}$ & $2.75 \mathrm{t} / \mathrm{ac}$ & $1.3 \mathrm{t} / \mathrm{ac}$ & $0.45 \mathrm{t} / \mathrm{ac}$ \\
\hline
\end{tabular}

Table.2 Suggestions for enhancing Jasmine production and marketing

\begin{tabular}{|r|l|c|}
\hline S.No. & \multicolumn{1}{|c|}{ Suggestions } & Per cent \\
\hline 1. & Storage room with advanced technologies & 56.00 \\
\hline 2. & Scent factory price fixation should support the farmers. & 63.00 \\
\hline 3. & Price stability during peak and lean seasons & 78.00 \\
\hline 4. & Need Flower plucking machine & 45.00 \\
\hline 5. & $\begin{array}{l}\text { Need Awareness on recommended Fertilizers, foliar spray and } \\
\text { pruning }\end{array}$ & 74.00 \\
\hline 6. & Need export procedures for GI product & 71.00 \\
\hline 7. & Opportunity to get higher price through GI Knowledge on GI & 68.00 \\
\hline 8. & $\begin{array}{l}\text { Farmers groups should be developed and should focus on small and } \\
\text { marginal farmers for getting remunerative prices. }\end{array}$ & 65.00 \\
\hline
\end{tabular}


Table.3 PRA- Simple Scoring method to assess the factors for the yield Gap

\begin{tabular}{|c|c|c|c|c|c|}
\hline S.No. & Content & No. of stones & Scores & $\%$ & Rank \\
\hline 1. & Drought situation ( scarcity for irrigation) & 00000000000000000 & 17 & 85 & 1 \\
\hline 2. & $\begin{array}{l}\text { High temperature which reduces the quality of flower production } \\
\text { (scorching and tip drying) }\end{array}$ & 000000000000000 & 15 & 75 & 3 \\
\hline 3. & No choice of variety-only one variety and no high yielding varieties & 000000000000 & 12 & 60 & 6 \\
\hline 4. & Using only complex fertilizers in improper ratios & 00000000000000 & 14 & 70 & 4 \\
\hline 5. & $\begin{array}{l}\text { No proper pruning (due to continuous harvest of flowers and lack of } \\
\text { awareness on the yield increase) }\end{array}$ & 0000000000000000 & 16 & 80 & 2 \\
\hline 6. & Not aware of split doses and foliar spray & 00000000 & 8 & 40 & 10 \\
\hline 7. & $\begin{array}{l}\text { Root rot and budworm are serious problems (weekly once applying } \\
\text { pesticides during peak flowering) }\end{array}$ & 0000000000000 & 13 & 65 & 5 \\
\hline 8. & $\begin{array}{l}\text { Getting advice from Private fertilizer and Pesticide shops\& } \\
\text { charging much cost for pesticides \& increasing the dosage }\end{array}$ & 000000000 & 10 & 50 & 8 \\
\hline 9. & $\begin{array}{l}\text { Need to go long distance for propagation material and } \\
\text { Tip drying at the time of planting( } 20 \% \text { death of seedlings })\end{array}$ & 00000000000000 & 14 & 70 & 4 \\
\hline 10. & Picking flowers after 11 a.m reduce yield and quality of flower & 00000000000 & 11 & 55 & 7 \\
\hline 11. & $\begin{array}{l}\text { Due to lack of awareness on the symptom of iron deficiency, spending } \\
\text { much amount for management }\end{array}$ & 0000000 & 7 & 35 & 11 \\
\hline 12. & Keeping jasmine crop more than 10 years without crop rotation & 000000000 & 9 & 45 & 9 \\
\hline
\end{tabular}


Table.4 Assessing the Production Constraints through Preference/Problem Ranking

\begin{tabular}{|c|c|c|c|c|c|c|c|c|c|c|}
\hline $\begin{array}{l}\text { Farmers } \\
\text { group }\end{array}$ & $\begin{array}{l}\text { Monsoon } \\
\text { failure }\end{array}$ & $\begin{array}{l}\text { High } \\
\text { Seedling } \\
\text { Cost } \\
\text { Rs.40,000/ac }\end{array}$ & $\begin{array}{l}\text { Un } \\
\text { Availability \& } \\
\text { high cost of } \\
\text { labour }\end{array}$ & $\begin{array}{l}\text { Weed } \\
\text { problem }\end{array}$ & $\begin{array}{l}\text { Not adopting } \\
\text { recommended } \\
\text { fertilizer doses }\end{array}$ & $\begin{array}{l}\text { Lack of } \\
\text { technical } \\
\text { knowledge on } \\
\text { split application } \\
\text { and foliar spray }\end{array}$ & $\begin{array}{l}\text { No proper } \\
\text { Pruning }\end{array}$ & $\begin{array}{l}\text { Delay in } \\
\text { input } \\
\text { supply }\end{array}$ & $\begin{array}{l}\text { Lack of } \\
\text { subsidies } \\
\text { for drip } \\
\text { irrigation }\end{array}$ & $\begin{array}{l}\text { Pest and disease } \\
\text { problem } \\
\text { (Root rot and } \\
\text { bud worm) }\end{array}$ \\
\hline I & 5 & 4 & 5 & 3 & 4 & 3 & 5 & 4 & 3 & 5 \\
\hline II & 4 & 3 & 5 & 2 & 5 & 2 & 4 & 3 & 4 & 5 \\
\hline III & 5 & 3 & 4 & 3 & 4 & 4 & 4 & 3 & 3 & 3 \\
\hline IV & 3 & 4 & 4 & 5 & 3 & 2 & 3 & 3 & 2 & 4 \\
\hline $\mathbf{V}$ & 5 & 1 & 4 & 3 & 3 & 3 & 3 & 2 & 2 & 4 \\
\hline VI & 3 & 4 & 5 & 4 & 3 & 3 & 5 & 3 & 2 & 5 \\
\hline score & 25 & 19 & 27 & 20 & 22 & 17 & 24 & 18 & 16 & 26 \\
\hline Mean & 4.2 & 3.2 & 4.5 & 3.3 & 3.7 & 2.8 & 4.0 & 3.0 & 2.7 & 4.3 \\
\hline Rank & III & VII & I & VI & $\mathbf{V}$ & IX & IV & VIII & $\mathbf{X}$ & II \\
\hline
\end{tabular}

Average Mean Score-3.6

Table.5 Assessing the Marketing Constraints through Preference/Problem Ranking

\begin{tabular}{|c|c|c|c|c|c|c|c|c|c|c|}
\hline $\begin{array}{l}\text { Farmers } \\
\text { group }\end{array}$ & $\begin{array}{c}\text { Commission } \\
\text { Agents }\end{array}$ & $\begin{array}{c}\text { Heavy } \\
\text { fluctuations } \\
\text { in the price }\end{array}$ & $\begin{array}{c}\text { High } \\
\text { Trans } \\
\text { port cost }\end{array}$ & Perish ability & $\begin{array}{c}\text { Lack of } \\
\text { Cold } \\
\text { storage } \\
\text { facilities }\end{array}$ & $\begin{array}{l}\text { Lack of technical } \\
\text { knowledge on } \\
\text { export of flowers } \\
\text { and GI }\end{array}$ & $\begin{array}{l}\text { Preharvest } \\
\text { agreement }\end{array}$ & $\begin{array}{l}\text { Off season } \\
\text { flowering- } \\
\text { low yield } \\
\text { and hike in } \\
\text { price }\end{array}$ & $\begin{array}{c}\text { Scent } \\
\text { factories } \\
\text { getting for } \\
\text { lower price }\end{array}$ & $\begin{array}{c}\text { Lack of } \\
\text { grading and } \\
\text { proper } \\
\text { weighing } \\
\text { machines }\end{array}$ \\
\hline I & 5 & 4 & 2 & 4 & 5 & 2 & 5 & 4 & 5 & 3 \\
\hline II & 5 & 5 & 3 & 3 & 5 & 5 & 5 & 2 & 4 & 4 \\
\hline III & 5 & 5 & 3 & 4 & 4 & 5 & 5 & 3 & 3 & 3 \\
\hline IV & 4 & 4 & 3 & 5 & 2 & 4 & 5 & 3 & 2 & 2 \\
\hline $\mathbf{V}$ & 5 & 4 & 3 & 4 & 2 & 3 & 3 & 2 & 3 & 4 \\
\hline VI & 5 & 5 & 5 & 5 & 4 & 4 & 5 & 4 & 3 & 5 \\
\hline score & 29 & 27 & 19 & 25 & 22 & 23 & 28 & 18 & 20 & 21 \\
\hline Mean & 4.8 & 4.5 & 3.2 & 4.2 & 3.7 & 3.8 & 4.7 & 3.0 & 3.3 & 3.5 \\
\hline Rank & I & III & IX & IV & VI & $\mathbf{V}$ & II & $\mathbf{X}$ & VIII & VII \\
\hline
\end{tabular}

Average Mean Score-3 
Further, the importance and benefits of Geographical Indication for Madurai malli should be disseminated among the farmers to get good market price in the national and International markets was felt by 68.00 percent of the farmers. Studies on marketing behaviour of GI Madurai malli may be undertaken to assess the need in international markets. This finding is in line with the findings of Rajeshwaran (2017).

Farmer groups should be developed and should focus on small and marginal farmers for getting remunerative prices was expressed by 65.00 percent of the farmers. Scent factory price fixation should support the farmers during the lean period was expressed by 63.00 percent of the farmers.

The farmers expect government should take initiatives to establish storage room with advanced technologies in order to maintain the flowers for long time and it was expressed by 56.00 percent of the farmers. Further the farmers expressed $(45.00 \%)$ that flower picking machineries have to be developed in order to manage the labour problem during peak seasons. To increase the production and productivity of jasmine, the farmers need awareness on recommended fertilizers and foliar spray for flower induction and pruning at proper time. Proper chemicals for pest and disease control are felt essential among the farmers. Frequent ICT enabled communication may be given through on the above aspects in order to reduce the yield gap.

With regard to marketing they need storage room with advanced technologies to keep the flowers and price stability during peak seasons. Further, the importance and benefits of Geographical Indication for Madurai malli should be disseminated among the farmers to get good market price in the national and International markets.

\section{References}

Ahiah. 2013. A study of flower cultivation practices of the farmers from the development block of the college of agriculture, Dapoli. A report of the Department of Agricultural extension, Konkan KrishiVidyapeetha, Dapoli: 33-40.

Janakirani, A. 1999. Identification of strategies for the development of and Research priorities for Jasmine. Unpub. M.Sc. (Ag.) Thesis, AC. \& RI., TNAU. Madurai.

Kaviarasan.K., Singh.D.R. Prawin Arya, 2015 An economic analysis of jasmine cultivation in

Rajeshwaran.M. (2017) Awareness on Geographical Indication (MaduraiMalli) and its Perceived Socio Economic Impact among Jasmine Growers of Madurai District Unpub. M.Sc. (Ag.) Thesis, AC. \& RI., TNAU., Madurai

Sivashankar. N. and K. K. Shashidhar 2011 Adoption Behaviour of Jasmine Cultivation in Bellary District of Karnataka State, Indian Res. J. Ext. Edu. 11 (1), January, 2011p.p.23

TamilNadu Biotech Articles, Agriculture, biotecharticles.com

The Hindu dated $13^{\text {th }}$ July 2012.

The Times of India dated August 24th 2014

Vairavan (2012) Change in temperature affecting jasmine yield Times of India, Aug 24, 2012, http://timesofindia.indiatimes.com/artic leshow

Vasanthi .R. 2015.An analytical study on jasmine cultivation in Madurai district of Tamil Nadu. Unpub. Ph.D. (Ag.) Thesis, AC \& RI, TNAU, Madurai. 


\section{How to cite this article:}

Janaki Rani. A and Murugan. P. P. 2020. Yield Gap and Constraints in Jasmine Cultivation and Suggestions to Increase the Production in Tamil Nadu, India. Int.J.Curr.Microbiol.App.Sci. 9(03): 1373-1381. doi: https://doi.org/10.20546/ijcmas.2020.903.159 